\title{
O duplo regime curatelar inaugurado pelo Estatuto da Pessoa com Deficiência: apresentação de aspectos civis e processuais ${ }^{1}$
}

\author{
The double curatelar regime established by the Brazilian Act on People with Disability \\ Inclusion (Federal Law n. 13.146/2015): presentation of civil and procedural aspects
}

\section{Resumo}

O presente artigo tem por intuito analisar o duplo regime curatelar inaugurado pela entrada em vigor do Estatuto da Pessoa com

Deficiência. Percebeu-se que existe, com as inovações trazidas pela nova legislação e as alterações promovidas no Código Civil e Código Processo Civil, uma nova regulamentação protetiva para as pessoas com deficiência, sendo possível apontar, além da tomada de decisão apoiada, duas formas de curatela: uma para os incapazes e uma para as pessoas com deficiência capazes que, como gestoras de sua própria deficiência, podem requerer auxílio para prática de determinados atos.

Palavras-chave: Pessoas com Deficiências, Estatuto da Pessoa Com Deficiência, Duplo Regime Curatelar.

\begin{abstract}
This essay aims to analyze the double curatelar regime instituted with the entry into force of the Brazilian Act on People with Disability Inclusion (Federal Law n. 13.146/2015). It was noticed that, with the innovations brought by the new legislation and the changes promoted in the Civil Code and Civil Procedure Code, there is a new protective regulation for people with disabilities: one regulation for the legally incapacitated and one for capable person with disability who, as manager of their own disabilities, require assistance in doing certain acts.
\end{abstract}

Keywords: People with Disabilities, Brazilian Act on People with Disabilities Inclusion, Double Curatelar Regime.

\section{Introdução}

Com o advento do Estatuto da Pessoa com Deficiência (EPD) muito vem se discutindo acerca do novo regime jurídico aplicável às pessoas com deficiência. Em virtude das alterações dos arts. 3ํㅡ e $4^{\circ}$ do Código Civil diverge a doutrina acerca da possibilidade de declarar a incapacidade das pessoas com deficiência mental ou intelectual e, como consequência, sobre a aplicação da curatela às pessoas com deficiência.

Este trabalho se propõe a analisar o regime curatelar aplicável às pessoas com deficiência mental ou intelectual, visto que são essas pessoas que podem vir a serem submetidas à curatela. Com essa finalidade, antes de adentrar propriamente na apresentação do duplo regime curatelar, optou-se por tratar sobre a possibilidade de as pessoas com deficiência serem consideradas incapazes, apesar da regra ser a da capacidade civil da pessoa com deficiência mental ou intelectual.

1 Este artigo é resultado do grupo de pesquisa "Transformações nas teorias sobre o processo e o Direito processual", vinculado à Universidade Federal da Bahia e cadastrado no Diretório Nacional de Grupos de Pesquisa do CNPQ (dgp.cnpq. br/dgp/espelhogrupo/7958378616800053). 


\section{Análise das alterações nos arts. $3^{\circ}$ e $4^{\circ}$ do Código Civil e o regime jurídico aplicável às pessoas com deficiência mental ou intelectual.}

Até a entrada em vigor do Estatuto, o Código Civil/2002 apresentava o regramento das incapacidades prevendo a incapacidade das pessoas com deficiência em decorrência de impedimentos/limitações mentais e intelectuais. As alterações dos artigos $3^{\circ}$ e $4^{\underline{0}}$ do CC instituídas pelo EPD garantem a essas pessoas uma nova condição no mundo jurídico, além de garantir um novo olhar ao tema. Os artigos referidos passaram a vigorar com a seguinte redação:

Art. $3^{\circ}$ São absolutamente incapazes de exercer pessoalmente os atos da vida civil os menores de 16 (dezesseis) anos. $^{2}$

Art. $4^{\circ}$ São incapazes, relativamente a certos atos ou à maneira de os exercer:

I - os maiores de dezesseis e menores de dezoito anos;

II - os ébrios habituais e os viciados em tóxico;

III - aqueles que, por causa transitória ou permanente, não puderem exprimir sua vontade;

IV - os pródigos.

Parágrafo único. A capacidade dos indígenas será regulada por legislação especial.

Percebe-se, pelo texto dos novos artigos do CC que, a partir da entrada do Estatuto, há uma desvinculação entre deficiência e incapacidade. ${ }^{3}$ Com as novas redações deixa-se de associar deficiência como causa justificante para ausência, redução ou incompletude de discernimento, visto que se passa a vislumbrar "que, a despeito da deficiência, a pessoa poderia ostentar alguma capacidade para exercer os atos da vida civil". ${ }^{4}$ Assim, as pessoas com transtorno mental, por exemplo, deixaram de figurar no rol dos

2 Comentando a incapacidade absoluta dos menores de 16 anos, Moacyr Petrocelli de Ávila Ribeiro chama atenção para a supressão pelo sistema da ação de interdição absoluta, já que os menores de idades não estão sujeitos à ação de interdição e não há mais hipótese de maiores de idade absolutamente incapazes (RIBEIRO, Moacyr Petrocelli de Ávila. Estatuto da pessoa com deficiência: a revisão da teoria das incapacidades e os reflexos jurídicos na ótica do notário e do registrador. Colégio Notarial do Brasil - Conselho Federal. Disponível em www.notariado.org.br. Acesso 17 de maio de 2018$).$

3 CORREIA, Átala. Estatuto da pessoa com deficiência traz inovações e dúvidas. Revista Síntese direito previdenciário. São Paulo, ano XVI, no 78, pp. 22-16, maio/jun. 2017, p.23. Ainda nesse sentido: DANELUZZI, Maria Helena Marques Braceiro e MATHIAS, Maria Ligia Coelho. Repercussão do Estatuto da Pessoa com Deficiência (Lei 13.146/2015), nas legislações civil e processual civil. Revista de Direito Privado. São Paulo, vol. 66, pp. 57-82, abril/jun.2016; BASILE, Felipe. Capacidade Civil e o Estatuto da Pessoa com deficiência. In Boletim do Legislativo $n^{\circ} 40$. Disponível em www12.senado.leg.br. Acesso 21 de maio de 2018; ARAUJO, Luiz Alberto David e COSTA FILHO, Waldir Macieira da. O Estatuto da Pessoa com Deficiência - EPCD (Lei 13.146, de 06.07.2015): Algumas novidades. Revista dos Tribunais. São Paulo, vol. 962, pp. 65-80, dez.2015. Disponível em www.mppa.mp.br. Acesso 31 de maio de 2018; FARIAS, Cristiano Chaves; CUNHA, Rogério Sanches e PINTO, Ronaldo Batista. Estatuto da pessoa com deficiência comentado artigo por artigo. 2ª ed. Salvador: Juspodivm, 2016, p. 241; BERLINI, Luciana e AMARAL, Paloma Francielly do. Os impactos do Estatuto da Pessoa com Deficiência no direito protetivo pátrio e sua antinomia com o novo código de processo civil. Revista da Escola Superior da Magistratura do Estado do Ceará. Fortaleza, vol. 15, no 2. 2017. Disponível em http://revistathemis.tjce.jus.br. Acesso 12 de julho de 2018; FARIAS, Cristiano Chaves de e ROSENVALD, Nelson. Curso de direito civil: parte geral e LINDB. 14aㅡ ed. Salvador: Juspodivm, 2016, p. 323.

4 MENEZES, Joyceanne Bezerra de. O risco de retrocesso: uma análise sobre a proposta de harmonização dos dispositivos do Código Civil, do CPC, do EPD e da CDPD a partir da alteração da Lei no 13.146 de 06 de julho de 2015 . Revista Brasileira de Direito Civil. Belo Horizonte, vol. 12, pp.137-171, abril/jun.2017. Disponível em www.ibdcivil.org.br. Acesso 01 de agosto de 2018. 
incapazes, ${ }^{5}$ com exceção dos ébrios habituais, viciados em tóxicos ${ }^{6}$ e pródigos diagnosticados com transtornos.

Além das alterações promovidas pelo EPD nos arts. $3^{\circ}$ e $4^{\underline{o}}$, o Estatuto reconhece a capacidade das pessoas com deficiência no art. $6^{\mathrm{o} 7}$ e no caput do art. 84, estipulando que "A pessoa com deficiência tem assegurado o direito ao exercício de sua capacidade legal em igualdade de condições com as demais pessoas".

Ademais, como consequência do reconhecimento da capacidade da pessoa com deficiência e das alterações promovidas nos arts. 3ํㅜ e $4^{\circ}$, o EPD altera a disciplina do art. 1.767 do CC. Esse diploma, regulando a curatela dos incapazes, antes da alteração promovida pelo Estatuto, estabelecia que se sujeitavam à curatela:

I - aqueles que, por enfermidade ou deficiência mental, não tiverem o necessário discernimento para os atos da vida civil; II - aqueles que, por outra causa duradoura, não puderem exprimir a sua vontade; III - os deficientes mentais, os ébrios habituais e os viciados em tóxicos; IV - os excepcionais sem completo desenvolvimento mental.

Após a mudança, passou a vigorar da seguinte maneira:

Estão sujeitos a curatela: I - aqueles que, por causa transitória ou permanente, não puderem exprimir sua vontade; II - (Revogado); III - os ébrios habituais e os viciados em tóxico; IV - (Revogado); V - os pródigos.

Uma das funções do EPD foi justamente reduzir a vulnerabilidade das pessoas com deficiência, para tentar ultrapassar as consequências das privações sofridas por elas ao longo das codificações brasileiras.

Sem dúvidas, a desvinculação entre deficiência e incapacidade é o maior símbolo dessa nova tentativa do legislador. Pode-se dizer que ela é fruto do estágio ${ }^{8}$ de proteção a esse grupo de vulneráveis pelo direito brasileiro que envolve: promover a proteção com respeito às diferenças, com base no que a

$5 \quad$ REQUIÃO, Maurício. As mudanças na capacidade e a inclusão da tomada de decisão apoiada a partir do Estatuto da pessoa com deficiência. Revista de Direito Contemporâneo. São Paulo, vol. 6, ano 3, pp. 37-54, jan./mar.2016, p.46. Disponível em http://www.egov.ufsc.br. Acesso 15 de novembro de 2017; FARIAS, Cristiano Chaves; CUNHA, Rogério Sanches e PINTO, Ronaldo Batista. Estatuto da pessoa com deficiência comentado artigo por artigo. 2a ed. Salvador: Juspodivm, 2016, p. 313; OLIVEIRA, Leonardo Alves de. O Estatuto da Pessoa com Deficiência (Lei n. 13.146/2015), seus direitos e o novo paradigma da capacidade civil. Revista Síntese direito previdenciário. São Paulo, Ano XVI, n 78, pp.50-61, maio/jun. 2017, p.59-60; VIEGAS, Cláudia Mara de Almeida Rabelo. As alterações da teoria das incapacidades, à luz do Estatuto da Pessoa com Deficiência. Revista Síntese direito previdenciário. São Paulo, ano XVI, nº 78, pp. 9-16, maio/jun. 2017, p.11-12; MACHADO, Diego Carvalho. Capacidade de agir e direitos da personalidade no ordenamento jurídico brasileiro: o caso do direito à privacidade. Revista Brasileira de Direito Civil. Belo Horizonte, vol. 8, no2, pp. 47-80, abr./jun.2016, p. 58.

6 GODINHO, Robson Renault. Comentários ao Código de Processo Civil - Dos procedimentos de jurisdição voluntária. GOUVEA, José Roberto e outros (coord.). São Paulo: Saraiva Educação, 2018, p. 376.

$7 \quad$ Segundo o art. 6o: "A deficiência não afeta a plena capacidade civil da pessoa, inclusive para: I - casar-se e constituir união estável; II - exercer direitos sexuais e reprodutivos; III - exercer o direito de decidir sobre o número de filhos e de ter acesso a informações adequadas sobre reprodução e planejamento familiar; IV - conservar sua fertilidade, sendo vedada a esterilização compulsória; V - exercer o direito à família e à convivência familiar e comunitária; e VI - exercer o direito à guarda, à tutela, à curatela e à adoção, como adotante ou adotando, em igualdade de oportunidades com as demais pessoas".

8 Trata-se do segundo estágio de proteção. O primeiro estágio foi o de combate à discriminação dos sujeitos considerados diferentes, momento em que se buscou a proteção dos vulneráveis ainda que tal proteção acarretasse a instauração de medidas com algum grau de segregação (REQUIÃO. Maurício. Estatuto da Pessoa com Deficiência, Incapacidade e Interdição. Salvador: Juspodivm, 2016, p.147). Sobre o primeiro estágio, Maurício Requião apresenta o exemplo trazido por Cláudia Marques e Bruno Miragem: a educação em escolas especiais para crianças surdas-mudas. Segundo esses últimos autores, "Com o espírito protetivo, por exemplo, políticas públicas mais antigas determinavam a segregação das crianças surdo-mudas em escolas especiais. Assim, para "proteger e tratar diferentemente os diferentes” eram excluídas estas crianças “diferentes” (surdas) do convívio das outras crianças (...)”(MARQUES, Cláudia Lima. MIRAGEM, Bruno. O novo direito privado e a proteção dos vulneráveis. São Paulo: Editora Revista dos tribunais, 2012, p. 111). 
doutrina alemã denominou de solidarprivatrecht, ou seja, um direito privado solidário ${ }^{9}$, que simboliza uma "perspectiva mais solidária e fraterna do direito privado nacional". ${ }^{10}$

As pessoas com impedimentos mentais ou intelectuais e, especificamente, as pessoas com transtornos mentais apresentam determinadas características que as diferenciam das outras pessoas, fragilizandoas, mas são, sem sombra de dúvidas, "seres humanos completos" ${ }^{11}$ e que merecem esse reconhecimento e respeito no tratamento jurídico que lhes é dado.

Além disso, é importante destacar que o desenvolvimento dos transtornos mentais é uma tendência crescente, ${ }^{12}$ não só no sentido do aumento das pessoas que os desenvolvem, mas, também, no crescimento das características que passam a ser categorizadas como transtorno mental. ${ }^{13} \mathrm{Com}$ essa nova realidade, a desvinculação entre a presença de um transtorno e a imediata categorização de incapacidade passa a ser uma forma de reconhecimento do direito brasileiro da complexidade do tema, aceitando a realidade de que os transtornos mentais não são, necessariamente, incapacitantes, garantindo assim a participação efetiva das pessoas na sociedade.

Cumpre deixar claro que, apesar de desvincular deficiência e incapacidade, não se pode defender que não há mais possibilidade de uma pessoa com deficiência ser declarada incapaz com base no ordenamento jurídico brasileiro.

Explica-se.

A supressão realizada pelo EPD no CC retirou as hipóteses de limitação à capacidade de agir que versavam sobre ausência (ou redução) de discernimento, ${ }^{14-15}$ que antes eram vinculadas à presença de uma deficiência, além de suprimir a hipótese de incapacidade dos excepcionais, sem desenvolvimento mental completo. Contudo, manteve no sistema, a incapacidade daqueles que não puderem exprimir vontade, que acaba por envolver o discernimento daquele que a manifesta, visto que só se pode qualificar um ato volitivo como livre e consciente, se presente o discernimento. ${ }^{16-17}$

Com isso, nota-se que a opção legislativa de impossibilidade de exercício de determinados direitos (e, em consequência, de invalidade dos atos praticados pelos sujeitos discriminados) agora está (e para frisar,

$9 \quad$ Não se quer neste trabalho defender que o sistema jurídico brasileiro apresenta um direito privado solidário, mas apenas ressaltar que alguns institutos vêm caminhando para essa direção e tem como base essa doutrina. Para uma análise mais aprofundada sobre o conceito de direito privado solidário, bem como a aproximação entre a realidade brasileira ver: MARQUES, Cláudia Lima. MIRAGEM, Bruno. O novo direito privado e a proteção dos vulneráveis. São Paulo: Editora Revista dos tribunais, 2012, p. 24-31.

10 MARQUES, Cláudia Lima. MIRAGEM, Bruno. O novo direito privado e a proteção dos vulneráveis. São Paulo: RT, 2012, p. 28.

11 REQUIÃO. Maurício. Estatuto da Pessoa com Deficiência, Incapacidade e Interdição. Salvador: Juspodivm, 2016, p.147.

12 REQUIÃO. Maurício. Estatuto da Pessoa com Deficiência, Incapacidade e Interdição. Salvador: Juspodivm, 2016, p.148.

13 Críticas severas foram feitas ao sistema classificatório DSM-5 por ampliar o rol dos transtornos mentais. (ARAÚJO, Álvaro Cabral. NETO LOTUFO, Francisco. A nova classificação Americana para os Transtornos Mentais - o DSM-5. Revista brasileira de terapia comportamental e cognitiva. Vol. 16, nº1, abril 2014, disponível em www.scielo.br. Acesso 05 de maio de 2018).

14 Mesmo não estando no texto expresso, Joyceanne Menezes afirma que não é a deficiência que retira a capacidade de exercício, mas a ausência de discernimento, de capacidade de querer e de entender os efeitos da escolha. Por essa razão, ela defende, conforme se verá adiante, novas redações aos arts. 3ํㅜ e $4^{\circ}$ do CC (MENEZES, Joyceanne Bezerra de. O risco de retrocesso: uma análise sobre a proposta de harmonização dos dispositivos do Código Civil, do CPC, do EPD e da CDPD a partir da alteração da Lei n ${ }^{\circ} 13.146$ de 06 de julho de 2015. Revista Brasileira de Direito Civil. Belo Horizonte, vol. 12, pp.137-171, abril/jun.2017. Disponível em www.ibdcivil.org.br. Acesso 01 de agosto de 2018).

15 O antigo inciso II do art. $4^{\circ}$ tinha a seguinte redação: "II - os ébrios habituais, os viciados em tóxicos, e os que, por deficiência mental, tenham o discernimento reduzido". E o antigo inciso I do art. 1.767: "I - aqueles que, por enfermidade ou deficiência mental, não tiverem o necessário discernimento para os atos da vida civil”.

16 Ao tratar sobre a validade dos negócios jurídicos Antônio Junqueira de Azevedo afirma que a declaração de vontade deve ser resultante de um processo volitivo, com plena consciência da realidade (AZEVEDO, Antônio Junqueira de. Negócio Jurídico. Existência, Validade e Eficácia. 4⿳⺈-a ed. São Paulo: Saraiva, 2002, p.43).

17 Alves, Brust-Renck, Ávila e Fernandes defendem que o discernimento é elemento necessário ao ato volitivo (ALVES, Rainer Grigolo de Oliveira; BRUST-RENCK, Priscila Goergen e ÁVILA, Ana Paula de Oliveira. FERNANDES, Márcia Santana. O discernimento no direito civil brasileiro e o Estatuto da Pessoa com Deficiência. In XII Semana de Extensão, Pesquisa e PósGraduação - SEPesq Centro Universitário Ritter dos Reis. Disponível em www.uniritter.edu.br. Acesso 04 de junho de 2018 ). 
somente agora, pós-reforma) associada às hipóteses em que se encontra uma inaptidão para expressar a vontade validamente, de forma consciente. Isto porque a declaração de vontade, ou seja, a efetiva exteriorização da vontade humana ${ }^{18}$ é o elemento nuclear do suporte fático dos atos jurídicos stricto sensu e dos negócios jurídicos, fatos jurídicos que hão de passar pelo plano da validade. ${ }^{19}$

No caso das pessoas com deficiência, a pressuposição de que suas vontades estariam viciadas em razão de um transtorno mental, por exemplo, foi afastada com a evolução da pesquisa nas áreas de psiquiatria e psicologia. Porém, essa evolução ocorrida nas áreas citadas, somente agora (pós-EPD) foi efetivamente integrada ao ordenamento jurídico.

Se não for o caso de impossibilidade de expressão de vontade, frisa-se, novamente, as pessoas com deficiência são capazes. Contudo, merece ser destacado que o reconhecimento da condição de capaz não implica uma total aptidão fática de realização pessoal de quaisquer atos ${ }^{20}$, já que existem mecanismos a disposição das pessoas com deficiência para auxiliálas na prática de determinados atos. Elas, a depender da deficiência, (e da maneira com que essa deficiência impacta nas suas vidas), podendo expressar suas vontades, têm total autonomia para gerir suas vidas, inclusive para verificar se necessitam ou não de apoio e requerer a instauração de medidas criadas pelo EPD.

Diante da possibilidade de se verificar pessoas com deficiência capazes e pessoas com deficiência incapazes é essencial entender a proteção jurídica fornecida pelo ordenamento a ambas, após a entrada em vigor do EPD. Para isso, aponta-se o surgimento de dois novos institutos: a tomada de decisão apoiada e a curatela de apoio, ambos que servirão às pessoas com deficiência capazes. Contudo, esta última (curatela de apoio) convive com a curatela dos incapazes, instaurando um duplo regime curatelar no sistema jurídico brasileiro que é o objeto de estudo central deste trabalho.

\section{Duplo regime curatelar.}

\subsection{Linhas Introdutórias.}

18 Menezes Cordeiro afirma que a declaração é o elemento central para a formação do negócio jurídico. Esta declaração é a "efectiva exteriorização da vontade humana" (MENEZES CORDEIRO, António. Tratado de direito civil português. Parte geral. 2a ed. Coimbra: Almedina, 2000, t. I, p. 339).

19 Os demais fatos jurídicos lícitos, em que a vontade não é dado do suporte fático, como o fatos jurídicos stricto sensu e os atos-fatos jurídicos e os fatos ilícitos lato sensu (incluindo os atos ilícitos) não estão sujeitos a transitar pelo plano da validade, pois não serão considerados nulos ou anuláveis (MELLO, Marcos Bernardes. Teoria do fato jurídico: Plano da existência. 13aㅡ ed. São Paulo: Saraiva, 2007, p.100).

20 Conforme ensina Oliveira Ascensão, toda incapacidade gera restrição à capacidade, porém nem toda restrição está vinculada à incapacidade. (ASCENSÃO, José de Oliveira. Direito Civil: Teoria Geral. Introdução. As pessoas. Os bens. $3^{\underline{a}}$ ed. São Paulo: Saraiva, 2010, vol.1, p. 140) 
A curatela pode ser entendida como um instituto ${ }^{21}$ pelo qual o curador fica responsável, após o processo de interdição, ${ }^{22}$ por administrar tanto os bens, como a pessoa do curatelado. ${ }^{23} \mathrm{O}$ instituto era, tradicionalmente, voltado ao maior considerado incapaz, ${ }^{24}$ buscando, além de proteger o tráfico jurídico e terceiros, a proteção desses adultos para auxiliá-los na prática de determinados atos. ${ }^{25} \mathrm{~A}$ curatela está prevista, no ordenamento jurídico do Brasil, desde os tempos coloniais - originariamente nas Ordenações Filipinas - e nele se mantém até os dias atuais. ${ }^{26}$

Após o EPD, o instituto passou a atender novas finalidades. É fundamental compreender, assim, o âmbito de funcionamento dele diante da nova disciplina.

Apesar da alteração mencionada no art. 1.767 do CC, permanece, evidentemente, no sistema jurídico, a curatela dos incapazes, já denominada pela doutrina de curatela interditiva ${ }^{27}$, imposta aos sujeitos descritos nos incisos desse artigo, que tem correspondência com o que dispõe o art. $4^{\circ}$ do CC. Essa curatela será aplicável aos incapazes, inclusive às pessoas com deficiência incapazes, assim consideradas, não pela deficiência, mas pela impossibilidade de manifestação de vontade, por serem ébrias habitual, viciadas em tóxicos ou pródigas.

Em linhas gerais, o procedimento de curatela interditiva pode ser promovido pelos legitimados no CPC, art. 747, devendo o autor, segundo art. 749, "especificar os fatos que demonstram a incapacidade do interditando para administrar seus bens e, se for o caso, para praticar atos da vida civil, bem como o momento em que a incapacidade se revelou". Tem o autor, ainda, o dever de juntar laudo médico para provar tais alegações. ${ }^{28}$

21 Joyceane Bezerra Menezes, ao fazer referência à curatela, afirma que ela seria um ônus. Porém, com a devida vênia ao entendimento da autora, a nosso ver, a curatela é, na realidade, um instituto que impõe um plexo de deveres, já que o dever jurídico, diferentemente do ônus, há de ser compulsoriamente cumprido, sob pena de uma sanção jurídica. A lei impõe um ônus como condição para a obtenção ou conservação, pelo próprio sujeito, de um interesse seu. Sobre a diferença entre ônus e dever, v. GRAU, Eros Roberto. Nota sobre a distinção entre obrigação, dever e ônus. Revista da Faculdade de Direito da Universidade de São Paulo. São Paulo, vol. 77. Disponível em www.revistas.usp.br. Acesso 03 de janeiro de 2018.

22 Uma observação é importante acerca da terminologia interdição. É sabido que o regime do CPC não oferece nítida compatibilização com as normas e diretrizes trazidas pelo Estatuto da Pessoa com Deficiência. A manutenção do termo "interdição", na seção IX, Do Capítulo XV (Dos procedimentos de jurisdição voluntária) é apenas um exemplo. Não à toa, o Projeto de Lei no 757 de 2015, ao menos no texto aprovado no Senado, visa alterar o título do da Seção IX para "Da Tomada de Decisão Apoiada e da Curatela”. Sobre o tema, Fredie Didier Jr. comenta que o EPD já havia promovido no Código Civil uma mudança no nomen iuris do procedimento, já que, onde pronunciava interdição, o legislador passou a referir "processo que define os termos da curatela". Para o autor "Há, claramente, uma tentativa de diminuir o impacto simbólico do termo 'interdição“” (DIDIER JR. Fredie. Da interdição. In WAMBIER, Teresa Arruda Alvim; DIDIER JR. Fredie; TALAMINI, Eduardo; DANTAS, Bruno. (coords.). Breves Comentários ao Novo Código de Processo Civil. 3ª ed. São Paulo: Revista dos Tribunais, 2016, p. 1.930).

23 MENEZES, Joyceane Bezerra de e CORREIA NETO. Jader de Figueiredo. Interdição e curatela no NOVO CPC à luz da dignidade da pessoa humana e do direito civil constitucional. In Relações Privadas e Democracia. Conpedi, 2014. Disponível em www.publicadireito.com.br. Acesso 27 de outubro de 2017.

24 REQUIÃO. Maurício. Estatuto da Pessoa com Deficiência, Incapacidade e Interdição. Salvador: Juspodivm, 2016, p. 164.

25 No direito português, falava-se em incapacidade por interdição e no direito francês de incapacité de protection (RIBEIRO, Geraldo Rocha. A proteç̧ão do incapaz adulto no direito português. Coimbra: Coimbra Editora, 2010, p.85).

26 Sobre os antecedentes históricos da curatela, v. MENEZES, Joyceane Bezerra de e CORREIA NETO. Jader de Figueiredo. Interdição e curatela no NOVO CPC à luz da dignidade da pessoa humana e do direito civil constitucional. In Relações Privadas e Democracia. Conpedi, 2014. Disponível em www.publicadireito.com.br. Acesso 27 de outubro de 2017.

27 A denominação utilizada no trabalho é a apontada por Diego Carvalho Machado (Capacidade de agir e direitos da personalidade no ordenamento jurídico brasileiro: o caso do direito à privacidade. Revista Brasileira de Direito Civil. Belo Horizonte, vol. 8, n², pp. 47-80, abr./jun. 2016. p. 57).

28 Conforme disciplina o art. 750 do CPC: "O requerente deverá juntar laudo médico para fazer prova de suas alegações ou informar a impossibilidade de fazê-lo”. 
Após instauração do processo de interdição, o juiz deve realizar a entrevista ${ }^{29}$ do interditando, podendo tal entrevista ser acompanhada por especialista (art. 751, $\$ 2^{\circ}$ do CPC), ${ }^{30}$ além de poder requerer a oitiva de parentes e de pessoas próximas $\left(\S^{\circ}{ }^{\circ} \text { do mesmo dispositivo }\right)^{31}$. Essa entrevista serve para o que juiz tome ciência da "vida, negócios, bens, vontades, preferências e laços familiares e afetivos e sobre o que mais lhe parecer necessário para convencimento" quanto à capacidade do interditando para praticar atos da vida civil. O interditando, caso não tenha requerido a medida, tem prazo de 15 dias ${ }^{32}$ para impugnar o pedido e continua sendo autorizado pelo $\$ 2^{\circ}$ do art. 752 a constituir advogado ${ }^{33}$.

Após o prazo para impugnação, far-se-á a produção de prova pericial, a fim de avaliar a capacidade do interditando para a prática dos atos da vida civil, devendo o laudo indicar os atos para os quais haverá necessidade de curatela. ${ }^{34}$ Em momento seguinte, o juiz proferirá sentença em que decretará a instauração da medida, nomeará curador e fixará os limites da curatela. ${ }^{35}$

O artigo 755 do CPC estabelece que, na sentença de interdição, o juiz, além de nomear o curador, "fixará os limites da curatela, segundo o estado e o desenvolvimento mental do interdito" e, para tanto, deve considerar "as características pessoais do interdito, observando suas potencialidades, habilidades, vontades e preferências". ${ }^{36}$

Apesar de a redação do caput do art. 755 do CPC afirmar que a sentença decreta a interdição, a eficácia da sentença de interdição é tema que gera divergência na doutrina. Maurício Requião entende que "a sentença declara a interdição" e "embora sujeita a recurso, produz efeito desde logo" tendo "qualquer recurso contra sentença que declara a interdição (...) somente efeito devolutivo". ${ }^{37-38}$ Barbosa Moreira afirma sobre o tema:

(...) a causa da incapacidade é a alienação mental, não a sentença de interdição. (...) Corretissimamente se dirá, portanto que a incapacidade não é gerada, mas apenas reconhecida pela sentença; (...) Daí não se infere, todavia, que a decretação da interdição seja ato meramente declaratório. Interditar uma pessoa não se reduz, em absoluto, a proclamar-lhe, pura e simplesmente a incapacidade.

(...)

$29 \quad$ No CPC/73 utilizava-se a terminologia interrogatório: “Art. 1.181. O interditando será citado para, em dia designado, comparecer perante o juiz, que o examinará, interrogando-o minuciosamente acerca de sua vida, negócios, bens e do mais que Ihe parecer necessário para ajuizar do seu estado mental, reduzidas a auto as perguntas e respostas”.

$30 \quad$ Art. 751 § $2^{\circ}$ A entrevista poderá ser acompanhada por especialista.

$31 \S 4^{\circ}$ A critério do juiz, poderá ser requisitada a oitiva de parentes e de pessoas próximas.

32 Art. 752. Dentro do prazo de 15 (quinze) dias contado da entrevista, o interditando poderá impugnar o pedido. Prazo maior do que o Código anterior: CPC/73 - Art. 1.182. Dentro do prazo de 5 (cinco) dias contados da audiência de interrogatório, poderá o interditando impugnar o pedido. Segundo Amanda Barbosa e Antonio Lago Jr., o prazo ainda poderá ser dilatado pelo magistrado (BARBOSA, Amanda Souza e LAGO JUNIOR. Antônio. Primeiras análises sobre o sistema de (in)capacidades, interdição e curatela pós estatuto da pessoa com deficiência e Código de Processo Civil. Revista de Direito Civil Contemporâneo. São Paulo, vol.8, pp.91-114, 2016, p. 103).

33 A constituição de advogado já era disciplinada pelo código anterior: Art. 1.182 § $2^{\circ}$ "Poderá o interditando constituir advogado para defender-se". No atual CPC: art. $752 \S 2^{\circ}$ "O interditando poderá constituir advogado, e, caso não o faça, deverá ser nomeado curador especial”.

34 Art. 753: "Decorrido o prazo previsto no art. 752, o juiz determinará a produção de prova pericial para avaliação da capacidade do interditando para praticar atos da vida civil”. § $2^{\circ}$ "O laudo pericial indicará especificadamente, se for o caso, os atos para os quais haverá necessidade de curatela”.

35 REQUIÃO. Maurício. Estatuto da Pessoa com Deficiência, Incapacidade e Interdição. Salvador: Juspodivm, 2016, p.180.

36 Art. 755 "Na sentença que decretar a interdição, o juiz": "I - nomeará curador, que poderá ser o requerente da interdição, e fixará os limites da curatela, segundo o estado e o desenvolvimento mental do interdito; II - considerará as características pessoais do interdito, observando suas potencialidades, habilidades, vontades e preferências".

37 REQUIÃO. Maurício. Estatuto da Pessoa com Deficiência, Incapacidade e Interdição. Salvador: Juspodivm, 2016, p.180.

38 Em sentindo diverso, Leonardo Schenk afirma que "a sentença de interdição tem natureza preponderantemente constitutiva na medida que, a partir e em razão dela, a situação jurídica do interdito é modificada (...)” (SCHENK, Leonardo Faria. Notas sobre a interdição no Código de Processo civil de 2015. Revista Eletrônica de Direito Processual - REDP. Vol. 15, jan./jun.2015. Periódico Semestral da Pós-Graduação Stricto Sensu em Direito Processual da UERJ. Disponível em www.epublicacoes.uerj.b. Acesso 29 de novembro de 2017) 
Vistas as coisas por tal prisma, não se pode deixar de perceber no ato feição constitutiva. ${ }^{39}$

Percebe-se, então, que para o autor a sentença de interdição contém eficácia constitutiva ${ }^{40}$, ao decretar a interdição. Apesar de ter eficácia constitutiva, a projeção dos efeitos ocorre ex nunc ${ }^{41-42}$. O efeito primordial da sentença, que é a sujeição do interdito à curatela, não é passível de se projetar ao passado, "a retroeficácia de que se cogita precisamente consistiria na invalidação de atos praticados, antes da interdição, pelo incapaz" ${ }^{43}$

Barbosa Moreira explica que se já existia alienação mental, os atos praticados seriam nulos, e para ele poderiam ser declarados nulos incidenter tantum. ${ }^{44}$ Porém, a época de sua obra, as pessoas com deficiência ainda estavam sob o manto da legislação que poderia os declarar absolutamente incapazes, tornando a nulidade de seus atos defensável.

Com a mudança no regime das incapacidades, é o caso de reconhecer que a interdição não invalida automaticamente os atos praticados antes da decisão, constituindo-se apenas material probatório para possível ação anulatória. Apesar de no projeto do CPC tal entendimento tenha sido concretizado no $\$ 5^{\circ}$ do art. 755, o dispositivo não permaneceu em vigor. ${ }^{45}$

Após a constituição da curatela aos incapazes, e, com isso, após a declaração da incapacidade, os atos contidos na sentença de instituição da curatela como atos que necessitam de curador para serem praticados serão inválidos se praticados sem o curador, visto que conforme art. 171 do Código Civil: "Além dos casos expressamente declarados na lei, é anulável o negócio jurídico: I - por incapacidade relativa do agente”.

Ao lado da curatela dos incapazes, apresentada acima, o EPD enuncia no art. 84, $\$ 1^{\circ}$, que "Quando necessário, a pessoa com deficiência será submetida à curatela, conforme a lei”. Antes, como se viu, em seu caput, o legislador esclarece que as pessoas com deficiência são capazes em igualdade de condições com as demais pessoas.

Percebe-se, então, que o Estatuto, além de alteraro art. $4^{\circ}$ e o art. 1.767 do Código Civil, revogando qualquer menção, nesses dispositivos, à incapacidade das pessoas com deficiências em razão especificamente da deficiência, atribui-lhes expressamente plena capacidade (caput do art. 84). Nada obstante, aponta a possibilidade de submetê-las à curatela.

Nesse novo quadro, então, a curatela deixa de ser instrumento apenas voltado a suprir incapacidade, para ser utilizada também em favor de sujeitos capazes - no que interessa a este trabalho, pessoas com deficiência mental ou intelectual- que estejam necessitando de uma proteção eventual. ${ }^{46}$ Pode-se

39 BARBOSA MOREIRA, José Carlos. Eficácia da Sentença de Interdição por Alienação Mental. Revista de Processo. São Paulo, n 43, ano 11, jul./set.1986, p. 14.

40 Robson Godinho constata que a interdição é ação constitutiva (GODINHO, Robson Renault. Comentários ao Código de Processo Civil - Dos procedimentos de jurisdição voluntária. GOUVEA, José Roberto e outros (coord.). São Paulo: Saraiva Educação, 2018, p. 345).

41 Explica Pontes de Miranda, comentando o CPC 1939, "O que contratou com o incapaz, antes da interdição, pode alegar a capacidade, prová-la, e obter, em processo diferente, que se julgue; porém, depois da interdição, pela força da sentença constitutiva, a sentença de validade seria contra a sentença de constituição da incapacidade, isto é, contra o que se publicou.” (PONTES DE MIRANDA, Francisco Cavalcanti. Comentários ao Código de Processo Civil. 2ạ ed. São Paulo: Forense, 1959, t. VIII, p. 35).

42 O STJ já se manifestou acerca da projeção de efeitos ex nunc da sentença de interdição. Por todos ver os seguintes julgamentos: BRASIL. Superior Tribunal de Justiça (quarta turma). Recurso Especial 1694984 MS 2017/0012081-0; Relator Ministro LUIS FELIPE SALOMÃO, Data de Julgamento: 14/11/2017, Data de Publicação: DJe 01/02/2018 e BRASIL. Superior Tribunal de Justiça (terceira turma). Recurso Especial 1251728 PE 2011/0094947-5, Relator Ministro PAULO DE TARSO SANSEVERINO, Data de Julgamento: 14/05/2013, Data de Publicação: DJe 23/05/2013.

43 BARBOSA MOREIRA, José Carlos. Eficácia da Sentença de Interdição por Alienação Mental. Revista de Processo, São Paulo, no 43, ano 11, jul./set. 1986, p. 15.

44 BARBOSA MOREIRA, José Carlos. Eficácia da Sentença de Interdição por Alienação Mental. Revista de Processo, São Paulo, no 43, ano 11, jul./set. 1986, p. 15-16.

45 REQUIÃO. Maurício. Estatuto da Pessoa com Deficiência, Incapacidade e Interdição. Salvador: Juspodivm, 2016, p.180, nota 490 .

46 REQUIÃO. Maurício. Estatuto da Pessoa com Deficiência, Incapacidade e Interdição. Salvador: Juspodivm, 2016, p. 152. 
dizer, assim, que, com o EPD, cria-se um novo tipo de curatela: ${ }^{47}$ a curatela das pessoas com deficiência capazes, que possam expressar vontade e não sejam ébrias habituais, viciadas em tóxicos ou pródigas, e que, eventualmente, julgam necessitar de apoio para a prática de determinados atos. Por essas razões, a curatela prevista no $\S^{0}{ }^{\circ}$ do EPD vem recebendo da doutrina o nome de curatela de apoio. ${ }^{48}$

Trata-se, portanto, de um regime jurídico especial de instituição de curatela em favor da pessoa capaz com deficiência. Interessa, pois, apontar quais são as características desse regime especial, buscando apresentar um quadro comparativo entre ela e a curatela interditiva.

\subsection{O regime jurídico especial disciplinador da curatela de apoio.}

A locução "conforme a lei", utilizada na parte final do $\$ 1^{0}$ do art. 84, diz respeito à atração do regime geral de curatela dos incapazes, do Código Civil, no que for compatível ao alcance das finalidades da curatela das pessoas com deficiência, reconhecidas pelo caput como capazes, ou seja, a curatela de apoio. Conforme adiantado acima, ao lado da curatela de apoio, permanece em pleno funcionamento no regime jurídico brasileiro a curatela interditiva. Os sujeitos que podem ser submetidos a esse tipo de curatela (curatela interditiva) são os que estão descritos no art. 1.767 do Código Civil, observadas ressalvas feitas pela lei, como é o caso da limitação de conteúdo imposta à curatela do pródigo.

Constata-se, assim, diante da análise do Código Civil e do EPD, a coexistência de dois regimes jurídicos de curatela no direito brasileiro: de um lado, um regime geral de curatela, regulado pelo Código Civil e procedimentalmente pelo Código de Processo Civil, construído tendo por premissa a tutela dos sujeitos incapazes, anterior ao advento do EPD e, de outro, um regime especial de curatela destinada a oferecer instrumentos de exercício de autonomia às pessoas com deficiência capazes. As normas do regime geral serão aplicáveis ao regime especial, desde que omissa a legislação especial e diante da compatibilidade das normas gerais com as especificidades estipuladas pelo regime especial. Assim, normas do EPD indicam o regime jurídico da curatela de apoio, enquanto as normas do CPC e do Código Civil alimentam a tutela dos incapazes e dos capazes com deficiência, no que com essa última função forem compatíveis e desde que no regramento do EPD não exista regra específica.

\subsection{Requisito do regime especial: necessidade da curatela de apoio.}

O Estatuto, ao determinar, após o reconhecimento da capacidade plena das pessoas com deficiência, que elas serão submetidas à curatela "quando necessário", não apresenta quais critérios preencherão esse conceito indeterminado. Agiu corretamente.

Explica-se.

Se não são mais incapazes, as pessoas com deficiência deverão se submeter à curatela quando entenderem ser necessária a medida. Elas, possuidoras de capacidade plena, e, por isso, aptas a manifestar vontade, devem gerir sua deficiência e a eventual necessidade de auxílio para prática de atos.

Então, o juiz estará limitado à análise do apoio requerido pela pessoa com deficiência na petição inicial ou por quem o faça, com sua anuência, não podendo, na sentença, constituir curador para atos que não foram requeridos.

Desse modo, não parece ser compatível com o regime especial alguns dispositivos do regime geral. Por exemplo, o art. 755 do CPC que indica que o juiz fixará os limites da curatela, de acordo com "o estado e o desenvolvimento mental do interdito", não pode ser aplicado à curatela de apoio. Com isso, o magistrado deve se limitar a avaliar as alegações e provas da necessidade de auxílio e a compatibilidade delas com os atos descritos pelo requerente como necessários.

47 Pablo Stolze e Rodolfo Pamplona Filho admitem que, ao lado da curatela dos incapazes, o EPD inaugura, "em face dos sujeitos alcançados por este microssistema," uma curatela com "uma nova estrutura e configuração" (Novo curso de direito civil. Parte Geral.14ª ed. E-book. São Paulo: Saraiva, 2012, vol.1, p. 1.348).

48 MACHADO, Diego Carvalho. Capacidade de agir e direitos da personalidade no ordenamento jurídico brasileiro: o caso do direito à privacidade. Revista Brasileira de Direito Civil. Belo Horizonte, vol. 8, no2, pp. 47-80, abr./jun.2016 p. 57. 


\subsection{A limitação da curatela de apoio aos atos de natureza patrimonial ou negocial.}

Também importa destacar uma característica essencial da curatela de apoio: a limitação ao seu conteúdo.

Desde o Código Beviláqua, até o advento do EPD, a curatela detinha um caráter patrimonial, ou seja, a preocupação do legislador se voltava à tutela e à administração dos bens do curatelado. Entretanto, a instauração da curatela possibilitava uma quase completa mitigação da personalidade do interditado ${ }^{49}$, porque a lei não estipulava que a medida era limitada aos atos de natureza patrimonial. ${ }^{50}$

Contudo, no $\S 3^{\circ 51}$ do art. 84 do EPD, o legislador previu expressamente que a curatela de pessoa com deficiência é medida protetiva extraordinária e que deverá ser proporcional às necessidades e às circunstâncias de cada caso, durando o menor tempo possível. Confirmou-se, então, a curatela como medida in extremis, que somente poderá ser utilizada nos limites da necessidade do curatelado. ${ }^{52}$

Mas, além de expressamente firmar a temporariedade e o caráter excepcional da medida curatelar da pessoa com deficiência, o EPD apresentou uma limitação ao seu conteúdo. No art. $85^{53}$ estabeleceu limites, de modo que a curatela da pessoa com deficiência somente afetará a prática de atos relacionados aos direitos de natureza patrimonial e negocial, preservando, assim, a autonomia referente ao exercício dos direitos existenciais. ${ }^{54}$ Com isso, não há mais que se vincular a curatela à substituição de vontade.

Ademais, o Estatuto enumera, no parágrafo $1^{\circ}$ do art. 85, exemplificadamente, direitos cuja administração a curatela não alcançará, como "o direito ao próprio corpo, à sexualidade, ao matrimônio, à privacidade, à educação, à saúde, ao trabalho e ao voto". 55

49 MENEZES, Joyceane Bezerra de e CORREIA NETO. Jader de Figueiredo. Interdição e curatela no NOVO CPC à luz da dignidade da pessoa humana e do direito civil constitucional. In Relaçôes Privadas e Democracia. Conpedi, 2014. Disponível em www.publicadireito.com.br. Acesso 27 de outubro de 2017; REQUIÃO. Maurício. Estatuto da Pessoa com Deficiência, Incapacidade e Interdição. Salvador: Juspodivm, 2016, p. 164-165; BARBOSA, Amanda Souza e LAGO JUNIOR. Antônio. Primeiras análises sobre o sistema de (in)capacidades, interdição e curatela pós estatuto da pessoa com deficiência e Código de Processo Civil. Revista de Direito Civil Contemporâneo. São Paulo, vol.8, pp.91-114, 2016, p.94.

50 A exceção desta regra seria, antes do EPD, o art. 1.782 do Código Civil, que versa sobre a interdição do pródigo. "Art. 1.782. A interdição do pródigo só o privará de, sem curador, emprestar, transigir, dar quitação, alienar, hipotecar, demandar ou ser demandado, e praticar, em geral, os atos que não sejam de mera administração".

51 Art. 84 " $\$ 3^{\circ}$ A definição de curatela de pessoa com deficiência constitui medida protetiva extraordinária, proporcional às necessidades e às circunstâncias de cada caso, e durará o menor tempo possível”.

52 MENEZES, Joyceane Bezerra de. O direito protetivo no Brasil após a convenção sobre a proteção da pessoa com deficiência: impactos do novo CPC e do Estatuto da Pessoa com Deficiência. Revista Eletrônica de Direito Civil. No 1 , ano 4, 2015. Disponível em http:/ / civilistica.com. Acesso 15 de novembro de 2017; SANTOS, Ivana Assis Cruz dos. O Estatuto da Pessoa com Deficiência e as Alterações no Código Civil de 2002. Revista Síntese direito previdenciário. São Paulo, $\mathrm{n}^{\circ}$ 78, ano XVI , pp. 27-36, maio./jun. 2017, p.32; CABRAL, Ana Clara. Estatuto da pessoa com deficiência e seu impacto no código civil. Revista Síntese direito previdenciário. São Paulo, nº 78, ano XVI, pp.47-48, maio./jun. 2017, p.47; MARTINS, Silvia Portes Rocha. O Estatuto da pessoa com deficiência e as alterações jurídicas relevantes no âmbito da capacidade civil. Revista dos Tribunais. São Paulo, vol. 105, nº 974, pp. 225-243, dez.2016, p. 231; BARBOZA, Heloisa Helena. A importância do CPC para o novo regime de capacidade civil. Revista da Escola da Magistratura do Estado do Rio de Janeiro. Rio de Janeiro, vol. 20, $\mathrm{n}^{\circ}$ 1, pp. 209-223, jan./abril. 2018, p. 216. GODINHO, Robson Renault. Comentários ao Código de Processo Civil - Dos procedimentos de jurisdição voluntária. GOUVEA, José Roberto e outros (coord.). São Paulo: Saraiva Educação, 2018, p. 343.

53 "Art. 85. A curatela afetará tão somente os atos relacionados aos direitos de natureza patrimonial e negocial".

54 A $7^{\text {a }}$ Câmara Cível do Tribunal de Justiça de Minas Gerais, no julgamento da apelação 1.0427.13.001117-9/001, reconheceu a curatela apenas para prática de atos de natureza patrimonial e negocial mesmo em caso de graves problemas psiquiátricos. (BRASIL. Tribunal de Justiça de Minas Gerais (7aㅡ Câmara Cível). Apelação Cível 1.0427.13.001117-9/001. Relator(a): Des.(a) Wilson Benevides. julgamento em 25/04/2017, publicado 05/05/2017) (Disponível em https:/ tj-mg. jusbrasil.com.br/jurisprudencia/455383371/apelacao-civel-ac-10427130011179001-mg. Acesso 27 de novembro de 2017). A mesma Câmara Cível, sob a relatoria da Des.(a) Alice Birchal, no julgamento da apelação cível 1.0245.13.011494-6/001, em fevereiro de 2017, entendeu que o inciso I do art. 755, que ainda será abordado neste trabalho, possibilita a ampliação dos poderes do curador para atos de natureza não patrimonial ou negocial (BRASIL.TJMG [7ª Câmara Cível]. Apelação cível 1.0245.13.011494-6/001. Relatora Desembargadora Alice Birchal. Julgamento em 14/02/2017, publicação 21 /02 /2017). Disponível em https://tj-mg.jusbrasil.com.br/jurisprudencia/432893401/apelacao-civel-ac-10245130114946001-mg. Acesso 27 de novembro de 2017.

55 Art. $85 \S 1^{\circ}$ "A definição da curatela não alcança o direito ao próprio corpo, à sexualidade, ao matrimônio, à privacidade, à educação, à saúde, ao trabalho e ao voto". 
Posterior ao EPD, o Projeto de Lei n 757 de $2015^{56}$, dos senadores Antônio Carlos Valadares, Paulo Paim e outros, no texto inicial, propôs alteração à redação do Art. 85 do EPD e a inserção de um quarto parágrafo. Segundo a proposta o dispositivo enunciaria que:

Art. 85. A curatela das pessoas com deficiência será limitada aos aspectos considerados estritamente necessários para a defesa e a promoção de seus interesses, preferencialmente limitando-se aos atos e negócios jurídicos de natureza patrimonial, respeitada a maior esfera possível de autonomia para os atos da vida civil.

$(\ldots)$

$\S 4^{\circ}$ As limitações previstas no $\S 1^{\circ}$ deste artigo não se aplicam nas hipóteses excepcionalíssimas do art. 1.772 da Lei $\mathrm{n}^{\mathrm{o}} 10.406$, de 10 de janeiro de $2002 .{ }^{57}$

Percebe-se que a tentativa dos senadores foi de não mais limitar a curatela aos atos patrimoniais, mas apenas preferencialmente aos atos dessa natureza. Tal iniciativa se manteve no substitutivo proposto pela Comissão de Direitos Humanos e Legislação Participativa sob a relatoria do Senador Telmário Mota. ${ }^{58}$ Entretanto, a Comissão de Constituição, Justiça e Cidadania, sob a relatoria da senadora Lídice da Mata, rejeitou as alterações propostas, conservando o texto original do Estatuto.

Nesse sentido, preserva-se ao curatelado capaz a sua autonomia privada em relação aos direitos de personalidade, não sendo possível limitar o exercício de situações subjetivas personalíssimas.

Assim, o curador da pessoa com deficiência capaz deve atuar com a finalidade de

facilitar a compreensão e prestar o adequado auxílio ao curatelado, seja, por exemplo, declarando a vontade deste a terceiros, traduzindo informações de maior grau de complexidade em linguagem simples e compreensível, ou, de modo mais ativo, formulando proposições sugestivas ao curatelado a fim de ajudá-lo em certas escolhas - v. g., concluir contrato de locação de imóvel residencial -, promovendo, enfim, na maior medida possível o discernimento do deficiente para a prática de atos da vida negocial. ${ }^{59}$

Percebe-se, então, uma alteração substancial da forma como o curador se mostra na relação entre ele e o curatelado. Especialmente na curatela da pessoa com deficiência, ele passa a prestar um auxílio ao curatelado para o melhor entendimento das questões.

Sem mencionar o tipo de curatela, Heloisa Barboza assegura que a possibilidade de interdição no âmbito dos direitos existenciais permanece no sistema de forma excepcional, mediante decisão judicial. Tal medida, segundo a autora, pode vir a ser instaurada para a proteção ou benefício da pessoa com deficiência ou para a proteção de terceiro. A defesa da hipótese se dá pela convicção de que a "plena capacidade das pessoas com deficiência não se pode dar com sacrifício de sua proteção e dignidade" ${ }^{60}$

Em sentido semelhante, o Desembargador Francisco Loureiro, da $1^{\circ}$ Câmara de Direito Privado do TJSP, no julgamento da apelação cível 0307037-84.2009.8.26.0100, afirmou que:

leitura rápida e superficial pode levar à conclusão de que todas as pessoas com enfermidade ou deficiência mental e que não tiverem condições de exprimir sua vontade por causa transitória ou permanente, antes consideradas

56 O Projeto de Lei $\mathrm{n}^{\circ} 757$ ainda se encontra em tramitação. O texto inicial apresentado pelos Senadores Antônio Carlos Valadares (PSB/SE), Paulo Paim (PT/RS) e outros sofreu alterações substanciais, algumas delas que serão comentadas ao longo deste trabalho. No dia 29 de novembro de 2018, o projeto foi remetido à Câmara dos Deputados, recebido sob o número 11.091/2018. Atualmente, encontra-se com encaminhamento às Comissões Defesa dos Direitos das Pessoas com Deficiência e Constituição e Justiça e de Cidadania. Para toda tramitação: http://www.camara.gov.br/proposicoesWeb/ fichadetramitacao?idProposicao=2187924. Acesso 08 de dezembro de 2018.

57 Disponível em https://www25.senado.leg.br. Acesso 18 de julho de 2018.

58 Disponível em https://www25.senado.leg.br. Acesso 18 de julho de 2018.

59 MACHADO, Diego Carvalho. Capacidade de agir e direitos da personalidade no ordenamento jurídico brasileiro: o caso do direito à privacidade. Revista Brasileira de Direito Civil. Belo Horizonte, vol. 8, no2, pp. 47-80, abr./jun.2016, p. 59-60.

60 BARBOZA, Heloisa Helena. A importância do CPC para o novo regime de capacidade civil. Revista da Escola da Magistratura do Estado do Rio de Janeiro. Rio de Janeiro, vol. 20, nº. 1, pp. 209-223, jan. / abr.2018, p. 217. 
absolutamente incapazes, a partir do Estatuto da Pessoa com Deficiência deixaram de sê-lo, e não mais se sujeitam à interdição, cujo procedimento deixou de ter previsão legal expressa no Código Civil. ${ }^{61}$

No mesmo voto, o desembargador se manifestou acerca dos atos sobre os quais pode recair a curatela:

Se a capacidade de entendimento e autodeterminação da pessoa com deficiência for, porém, reduzida em maior ou menor grau, afigura-se perfeitamente possível a recomendável a instituição de curatela ou do procedimento de tomada de decisão apoiada para a consecução de determinados atos, especialmente aqueles de ordem patrimonial. Ressalte-se que mesmo a curatela poderá ser parcial ou total, dependendo do grau de comprometimento das faculdades mentais do interessado, a ser avaliado por meio de perícia.

(...)

Em suma, uma interpretação sistemática e teleológica do Estatuto da Pessoa com Deficiência impõe a conclusão de que as pessoas que não consigam exprimir sua vontade por causa transitória ou permanente - por exemplo, doença mental que reduza seu discernimento -, devem ser consideradas relativamente incapazes, pois em geral conservam sua autonomia para a prática de atos de natureza existencial, relacionados aos direitos da personalidade, a exemplo dos direitos sexuais e reprodutivos, e aqueles relacionados ao planejamento familiar.

Todavia, dependendo do grau de comprometimento das faculdades mentais da pessoa, poderá ela submeter-se à curatela total ou parcial, que abrangerá eminentemente os atos de natureza patrimonial e negocial, ou então optar pelo processo de tomada de decisão apoiada para a prática de atos diversos. ${ }^{62}$

É indispensável observar que o desembargador faz uso de expressões indicativas de que qualquer curatela deve "preferencialmente" incidir sobre atos patrimoniais, não sendo impossível, entretanto encontrar situações em que a curatela (mas, nesse caso, somente a curatela interditiva, reservada aos incapazes) possa abranger atos de natureza personalíssima.

Observa-se, então, que a manutenção da hipótese de incapacidade para aqueles que, por causa transitória ou permanente, não puderem exprimir sua vontade implica dizer que: se em decorrência de qualquer circunstância, entre elas a deficiência mental ou intelectual, ${ }^{63}$ a pessoa não consiga expressar sua vontade ela será considerada relativamente incapaz, ${ }^{64} \mathrm{e}$, será submetida à curatela interditiva com possibilidade de sofrer restrição para prática de atos de natureza patrimonial ou não-patrimonial. ${ }^{65}$

Esse entendimento advém não só pelo fato de o EPD ter apontado uma restrição de instituição de curatela apenas à curatela das pessoas com deficiência, mas também pelos textos dos arts. 749 e 751 do CPC que mencionam expressamente a necessidade de análise da viabilidade do interditando para prática de atos da vida civil, sem, em momento algum, limitá-los aos atos negociais ou patrimoniais.

61 BRASIL. Tribunal de Justiça de São Paulo (1ª Câmara de Direito Privado), Apelação Cível 0307037-84.2009.8.26.0100, Relator Des. Francisco Loureiro, voto 29.643. Disponível em http:/ / arpenbrasil.org.br. Acesso 07 de junho de 2018.

62 BRASIL. Tribunal de Justiça de São Paulo (1ª Câmara de Direito Privado), Apelação Cível 0307037-84.2009.8.26.0100, Relator Des. Francisco Loureiro, voto 29.643. Disponível em http:/ / arpenbrasil.org.br. Acesso 07 de junho de 2018.

63 Nesse sentido, Stella Camlot Reicher afirma que “a impossibilidade de expressão da vontade por causa transitória ou permanente ainda deixe margem para que pessoas com deficiência com dificuldades de expressar sua vontade sejam colocadas em situação de curatela." (A capacidade legal das pessoas com deficiência. Disponível em www.apaesp.org.br. Acesso 05 de junho de 2018).

64 FARIAS, Cristiano Chaves. CUNHA, Rogério Sanches. PINTO, Ronaldo Batista. Estatuto da pessoa com deficiência comentado artigo por artigo. $2^{\mathrm{a}}$ ed. Salvador: Juspodivm, 2016, p. 313-314; FARIAS, Cristiano Chaves de. ROSENVALD, Nelson. Curso de direito civil: parte geral e LINDB. 14- ed. Salvador: Juspodivm, 2016, p. 335. Átala Correia afirma que tal hipótese abarcaria os casos de deficiência mental severa (CORREIA, Átala. Estatuto da pessoa com deficiência traz inovações e dúvidas. Revista Síntese direito previdenciário. São Paulo, no 78, ano XVI, pp. 22-26, maio/jun. 2017, p.24).

65 Com mesmo entendimento: BERLINI, Luciana; AMARAL, Paloma Francielly do. Os impactos do Estatuto da Pessoa com Deficiência no direito protetivo pátrio e sua antinomia com o novo código de processo civil. Revista da Escola Superior da Magistratura do Estado do Ceará. Fortaleza, vol. 15, no 2, 2017. Disponível em http:/ / revistathemis.tjce.jus.br. Acesso 12 de julho de 2018. Porém, em sentido diverso, FARIAS, CUNHA e PINTO afirmam que "Mesmo que a pessoa com deficiência não possa exprimir a sua vontade plenamente e, por conta disso, esteja em situação de curatela, está assegurada a sua autonomia existencial" (FARIAS, Cristiano Chaves de. CUNHA, Rogério Sanches. PINTO, Ronaldo Batista. Estatuto da pessoa com deficiência comentado artigo por artigo. 2a ed. Salvador: Juspodivm, 2016. p.64). Para nós, porém, como dito, não há como se preservar autonomia de exercício amplo de direitos a alguém que não possa expressar sua vontade. 


\subsection{A legitimidade para requerer a curatela de apoio.}

Ao tratar acima da curatela interditiva, mencionou-se que o CPC/15 estabelece, no art. $747^{66}$, a legitimidade ativa para a ação de interdição. Esse dispositivo possui um rol maior que o CPC anterior, pois este não possibilitava a propositura pelo representante da entidade em que o interditando se encontra abrigado ${ }^{67}$ sendo a legitimidade desses entes é extraordinária, podendo atuar em conjunto ou isoladamente. ${ }^{68}$

É importante mencionar, no tocante à legitimidade, a discussão acerca da autointerdição. O EPD, em seu art. 114, que alterou o Código Civil, incluiu no art. $1.768,{ }^{69}$ rol de legitimados para promover a curatela, o inciso IV, que define o próprio interessado como apto a requerê-la ${ }^{70}$ Porém, o CPC não elencou no art. 747 o interditando como legitimado, e mais, revogou o art. 1.768, ${ }^{71}$ após a entrada em vigor do Estatuto, sem observar a inserção feita no artigo revogado. Desse modo, num primeiro momento, se poderia assumir que a pessoa com deficiência só pode exercer a autointerdição no lapso temporal entre a entrada em vigor do Estatuto e a entrada em vigor do CPC. ${ }^{72}$ Fredie Didier Jr. defende que a revogação feita pelo CPC considerou a legislação civil da época, não sendo possível revogar o item que inseria a pessoa com deficiência como promovedora da curatela. Com isso, para o autor, mantem-se no sistema a possibilidade de autointerdição. ${ }^{73}$ Entretanto, mesmo sem o posicionamento de revogação parcial do art. 1.768, é plausível sustentar a autointerdição, com fundamento na Convenção sobre os Direitos da Pessoa

66 Art. 747. A interdição pode ser promovida: I - pelo cônjuge ou companheiro; II - pelos parentes ou tutores; III - pelo representante da entidade em que se encontra abrigado o interditando; IV - pelo Ministério Público.

67 Maurício Requião, ao tratar sobre o tema, faz referência à necessidade de regulamentação acerca dos requisitos que as instituições devem cumprir para serem aptas a propor a ação. (REQUIÃO. Maurício. Estatuto da Pessoa com Deficiência, Incapacidade e Interdição. Salvador: Juspodivm, 2016, p.171). No Projeto de lei $757 / 2015$ já mencionado, tenta-se solucionar essa e outras questões de direito intertemporal. Disponível em https://www25.senado.leg.br. Acesso 28 de novembro de 2017.

68 SCHENK, Leonardo Faria. Notas sobre a interdição no Código de Processo civil de 2015. Revista Eletrônica de Direito Processual - REDP. Rio de Janeiro, vol. 15, jan./jun. 2015. Periódico Semestral da Pós-Graduação Stricto Sensu em Direito Processual da UERJ. Disponível em www.e-publicacoes.uerj.b. Acesso 29 de novembro de 2017.

69 Art. 1.768. O processo que define os termos da curatela deve ser promovido: IV - pela própria pessoa.

70 Trata-se, em verdade, de antiga sugestão doutrinária promovida por Alcides de Mendonça Lima que afirmou, apesar de o Código que o autor comentava não conter a hipótese expressamente, que "ninguém velará mais por si mesmo do que o próprio interessado." (LIMA, Alcides Mendonça. Comentários ao Código de Processo Civil. São Paulo: RT, 1982, vol. VII, p. 436).

71 O dispositivo 1.072, II, do CPC, revogou o art. 1.678: Art. 1.072: “Revogam-se: II - os arts. 227, caput, 229, 230, 456, 1.482, 1.483 e 1.768 a 1.773 da Lei no 10.406, de 10 de janeiro de 2002 (Código Civil)".

72 REQUIÃO. Maurício. Estatuto da Pessoa com Deficiência, Incapacidade e Interdição. Salvador: Juspodivm, 2016, p.171-172.

73 DIDIER JR. Fredie. Estatuto da pessoa com deficiência, código de processo civil de 2015 e código civil: uma primeira reflexão. Disponível em http:/ / www.frediedidier.com.br / Acesso 27de novembro de 2017. No sentido de reconhecer a legitimidade ativa do interditando: MENEZES, Joyceane Bezerra de. O direito protetivo no Brasil após a convenção sobre a proteção da pessoa com deficiência: impactos do novo CPC e do Estatuto da Pessoa com Deficiência. Revista Eletrônica de Direito Civil. No $^{\circ}$ 1, ano 4, 2015. Disponível em http:/ / civilistica.com. Acesso 15 de novembro de 2017; ARAUJO, Luiz Alberto David. COSTA FILHO, Waldir Macieira da. O Estatuto da Pessoa com Deficiência - EPCD (Lei 13.146, de 06.07.2015): Algumas novidades. Revista dos Tribunais, São Paulo, vol. 962, pp.65-80, dez./2015. Disponível em www.mppa.mp.br. Acesso 31 de maio de 2018. E, ainda, REQUIÃO. Maurício. Estatuto da Pessoa com Deficiência, Incapacidade e Interdição. Salvador: Juspodivm, 2016. Este autor defende que o ideal seria a propositura de um projeto de lei que determinasse a inserção de um novo inciso no art. 747 do CPC. 
com Deficiência. ${ }^{74}$ Assim, defende-se que de fato há no sistema a viabilidade do processo instituidor da curatela ser ajuizado pelo próprio beneficiário. ${ }^{75}$

Com essa premissa, passa-se a análise da seguinte questão: a curatela de apoio pode ser requerida pelos mesmos legitimados do art. 747 do CPC?

Como já dito, no caput do art. 84, ficou fixada a capacidade plena da pessoa com deficiência. Já no $1^{\circ}$ menciona-se que quando necessário, "a pessoa com deficiência será submetida à curatela, conforme a lei” e, continua no $\$ 2^{\circ}$, estatuindo que à curatela do $\$ 1^{\circ}$ tem-se como alternativa a tomada de decisão apoiada.

Apesar de o texto do $\$ 1^{\circ}$ do art. 84 mencionar que "a pessoa com deficiência será submetida à curatela", não faz sentindo, diante da capacidade da pessoa com deficiência, vislumbrar hipótese de terceiros requererem a constituição de curatela, sem a anuência dela. Dessa forma, só será possível o deferimento da constituição da curatela de apoio por outro legitimado que não a própria pessoa com deficiência, se ela, sendo intimada no processo de constituição da curatela intentado por um dos legitimados do art. 747 do CPC, não impugnar o pedido nos termos do art. 752 do diploma processual, ou declarar expressamente a sua concordância ${ }^{76}$ Isto porque, apesar da deficiência, o reconhecimento da capacidade garante o direito de se autogerir, inclusive para escolher qual a medida de apoio é mais adequada.

Se, contudo, se verificar que não se trata de pessoa com deficiência capaz, mas sim de incapacidade segue-se a regra do regime geral, com os legitimados especificados no art. 747 do CPC, incluindo o próprio interditando como legitimado. ${ }^{77}$

Com a premissa de que a legitimidade para requerer a constituição de curatela de apoio é da pessoa com deficiência, não se aplicará a essa curatela o disposto no art. 748 do CPC, que cuida da legitimidade do Ministério Público para promover a interdição. ${ }^{78}$

74 Esse é o entendimento de BARBOSA, Amanda Souza e LAGO JUNIOR. Antônio. Primeiras análises sobre o sistema de (in)capacidades, interdição e curatela pós estatuto da pessoa com deficiência e Código de Processo Civil. Revista de Direito Civil Contemporâneo. São Paulo, vol.8, pp.91-114, 2016, p. 98. Aderimos a ele, de modo que defendemos que é possível extrair a possibilidade de autointerdição pela interpretação sistemática do EPD com a Convenção sobre Direitos Humanos das Pessoas com Deficiência. O Fórum Permanente de Processualistas Civis, versando sobre a autointerdição, editou o enunciado 680, in verbis "Admite-se pedido de autointerdição e de levantamento da própria interdição a partir da vigência do Estatuto da Pessoa com Deficiência”.

75 Sobre o tema Rosa Nery entende que "o comando do EPD de especificamente alterar o texto de artigos revogados implicaria repristinação deles e, por isso, as alterações que operou em artigos já revogados não se consideram escritas” (NERY, Rosa Maria Barreto Borriello de Andrade. O Estatuto da Pessoa com Deficiência (L. 13146, de 6.7.2015 - EPD) (Notícia do Novo Sistema Jurídico Brasileiro). Revista Jurídica Luso-Brasileira. Ano 2, nº 1, pp. 1541-1561, 2016. Disponível em www.cidp.pt. Acesso 12 de julho de 2018).

76 Trata-se aqui de entendimento que muito se assemelha com a figura da curatela-mandato do revogado art. 1.780 do CC. Nessa curatela, criada para o enfermo e pessoa com deficiência física, logo não destinada a um incapaz, cabia ao próprio interessado requerê-la ou, como afirmou Maria Berenice Dias, a qualquer das pessoas legitimadas desde que com a concordância do curatelado. A autora ainda explica que a curatela-mandato possuía a vantagem, em relação à procuração, pois nessa última perdia-se a eficácia caso o outorgante incidisse em alguma das causas de interdição (DIAS, Maria Berenice. Manual de Direito das Famílias. São Paulo: Revista dos Tribunais, 2015. p. 691-692).

77 Robson Godinho, ao tratar sobre a autointerdição, afirma que se a pessoa admitir que necessita de interdição por ser incapaz é necessária uma regularização procedimental, devendo ser nomeado curador provisório para assistir o autor (GODINHO, Robson Renault. Comentários ao Código de Processo Civil - Dos procedimentos de jurisdição voluntária. GOUVEA, José Roberto e outros (coord.). São Paulo: Saraiva Educação, 2018, p. 368).

78 Acerca da legitimidade do Ministério Público, que, como dissemos, serve apenas a curatela do regime geral, também é possível apontar problemas de direito intertemporal. O EPD alterou o art. 1.769 do Código Civil, de modo que o MP poderá promover o processo nos casos de deficiência decorrente de impedimentos intelectuais ou mentais, se a interdição não for promovida por algum dos legitimados ou se forem menores ou incapazes as pessoas legitimadas. Porém, posterior à alteração do Estatuto, o CPC revogou o art. 1.769 do CC e regulamentou a legitimação do MP no art. 748: "Art. 748. O Ministério Público só promoverá interdição em caso de doença mental grave: I - se as pessoas designadas nos incisos I, II e III do art. 747 não existirem ou não promoverem a interdição; II - se, existindo, forem incapazes as pessoas mencionadas nos incisos I e II do art. 747". Com a devida vênia ao entendimento apresentado por Fredie Didier Jr. no sentido de que haveria revogação tácita do CPC, se segue, aqui, o entendimento de que se encontra em vigor o Código de Processo Civil. Sendo assim, a legitimidade do MP é subsidiária e só ocorre em caso de doença mental grave, ou segundo o que se analisou anteriormente transtorno mental grave, e se se verificar (e se comprovar) a inexistência ou inércia das pessoas designadas 


\subsection{Validade dos atos praticados sem curador.}

Assim como na curatela interditiva, na curatela de apoio, com a instauração da medida, tornar-se necessária a presença do curador/apoiador para prática dos atos descritos na sentença de curatela. Evidente que a invalidade dos atos praticados pela pessoa com deficiência capaz sem o curador não terá o mesmo fundamento da invalidade dos atos dos incapazes, qual seja, o art. 171 do Código Civil.

É certo que o juiz, na sentença de constituição da curatela de apoio, considerará, apesar da deficiência da parte, a sua capacidade de autogestão. Entretanto, declarará a necessidade, apresentada pela própria pessoa com deficiência com sua anuência, de auxílio para prática de certos atos negociais ou patrimoniais. Com isso estabelecerá restrições à capacidade que servem como proteção não só a pessoa com deficiência, mas também ao terceiro que com ela negocia. Trata-se de um requisito formal de validade dos negócios celebrados pela pessoa com deficiência capaz curatelada, que tem por consequência a presunção de validade dos atos praticados por ela, com auxílio de seu curador.

Ocorre que, como afirmado, o Código Civil no art. $171^{79}$ não traz essa hipótese de anulabilidade dos negócios jurídicos. Ao que parece, o referido dispositivo não foi compatibilizado com a nova sistemática do EPD, visto que a sentença que constitui a curatela, mesmo tratando-se da curatela de apoio, impõe a necessidade de auxílio para prática de determinados atos. Assim, após a prolação da sentença, nada mais protetivo do que impor a presença do curador/apoiador para os atos descritos. A aplicabilidade do art. 171 a esses casos, contudo, trata-se de uma proposta de lege ferenda.

\section{Conclusão.}

Por tudo que foi apresentado, pode-se concluir que a pessoa com deficiência mental ou intelectual, apesar da nova disciplina dada ao regime das incapacidades pelo EPD que impõe a regra geral da capacidade civil plena, pode ainda ser considerada relativamente incapaz se se enquadrar em algumas das hipóteses do art. 4º do Código Civil.

Sendo relativamente incapaz a pessoa com deficiência mental ou intelectual deve ser submetida à curatela interditiva. Porém, sendo capaz, mas observando que necessita de apoio para prática de determinados atos, a pessoa com deficiência pode se valer, além da tomada de decisão apoiada, da curatela de apoio. Trata-se de uma curatela especial que tem características próprias, tais como legitimidade única da pessoa com deficiência e limitação de conteúdo que convive e se utilizada de normas da curatela dos incapazes, mas que com ela não se confunde.

\section{Referências.}

ALVES, Rainer Grigolo de Oliveira; BRUST-RENCK, Priscila Goergen e ÁVILA, Ana Paula de Oliveira. FERNANDES, Márcia Santana. O discernimento no direito civil brasileiro e o Estatuto da Pessoa com Deficiência. In XII Semana de Extensão, Pesquisa e Pós-Graduação - SEPesq Centro Universitário Ritter dos Reis. Disponível em www.uniritter.edu.br. Acesso 04 de junho de 2018.

nos incisos I, II e III do art. 747 ou a incapacidade daquelas indicadas nos seus incisos I e II. (MENEZES, Joyceane Bezerra de. O direito protetivo no Brasil após a convenção sobre a proteção da pessoa com deficiência: impactos do novo CPC e do Estatuto da Pessoa com Deficiência. Revista Eletrônica de Direito Civil. No 1, ano 4, 2015. Disponível em http: / / civilistica.com. Acesso 15 de novembro de 2017). Também abordam a legitimidade do Ministério Público: REQUIÃO. Maurício. Estatuto da Pessoa com Deficiência, Incapacidade e Interdição. Salvador: Juspodivm, 2016, p. 172. SCHENK, Leonardo Faria. Notas sobre a interdição no Código de Processo civil de 2015. Revista Eletrônica de Direito Processual - REDP. Rio de Janeiro, vol. 15, jan./jun.2015. Periódico Semestral da Pós-Graduação Stricto Sensu em Direito Processual da UERJ. Disponível em www.epublicacoes.uerj.b. Acesso 29 de novembro de 2017.

79 “Art. 171. Além dos casos expressamente declarados na lei, é anulável o negócio jurídico: I - por incapacidade relativa do agente; II - por vício resultante de erro, dolo, coação, estado de perigo, lesão ou fraude contra credores”. 
ARAÚJO, Álvaro Cabral. NETO LOTUFO, Francisco. A nova classificação Americana para os Transtornos Mentais - o DSM-5. Revista brasileira de terapia comportamental e cognitiva. Vol. 16, ${ }^{\circ} 1$, abril 2014, disponível em www.scielo.br. Acesso 05 de maio de 2018.

ARAUJO, Luiz Alberto David e COSTA FILHO, Waldir Macieira da. O Estatuto da Pessoa com Deficiência - EPCD (Lei 13.146, de 06.07.2015): Algumas novidades. Revista dos Tribunais. São Paulo, vol. 962, pp. 65-80, dez.2015. Disponível em www.mppa.mp.br. Acesso 31 de maio de 2018.

ASCENSÃO, José de Oliveira. Direito Civil: Teoria Geral. Introdução. As pessoas. Os bens. $3^{\underline{a}}$ ed. São Paulo: Saraiva, 2010, vol.1.

AZEVEDO, Antônio Junqueira de. Negócio Jurídico. Existência, Validade e Eficácia. $4^{\mathrm{a}}$ ed. São Paulo: Saraiva, 2002.

BARBOSA, Amanda Souza e LAGO JUNIOR. Antônio. Primeiras análises sobre o sistema de (in) capacidades, interdição e curatela pós estatuto da pessoa com deficiência e Código de Processo Civil. Revista de Direito Civil Contemporâneo. São Paulo, vol.8, pp.91-114, 2016.

BARBOSA MOREIRA, José Carlos. Eficácia da Sentença de Interdição por Alienação Mental. Revista de Processo. São Paulo, nº 43, ano 11, jul./set.1986.

BARBOZA, Heloisa Helena. A importância do CPC para o novo regime de capacidade civil. Revista da Escola da Magistratura do Estado do Rio de Janeiro. Rio de Janeiro, vol. 20, nº 1, pp. 209-223, jan./abril. 2018.

BASILE, Felipe. Capacidade Civil e o Estatuto da Pessoa com deficiência. In Boletim do Legislativo $n^{\circ} 40$. Disponível em www12.senado.leg.br. Acesso 21 de maio de 2018.

BERLINI, Luciana e AMARAL, Paloma Francielly do. Os impactos do Estatuto da Pessoa com Deficiência no direito protetivo pátrio e sua antinomia com o novo código de processo civil. Revista da Escola Superior da Magistratura do Estado do Ceará. Fortaleza, vol. 15, no 2. 2017. Disponível em http:// revistathemis.tjce.jus.br. Acesso 12 de julho de 2018.

CABRAL, Ana Clara. Estatuto da pessoa com deficiência e seu impacto no código civil. Revista Síntese direito previdenciário. São Paulo, nº 78, ano XVI, pp.47-48, maio/jun. 2017.

CORREIA, Átala. Estatuto da pessoa com deficiência traz inovações e dúvidas. Revista Síntese direito previdenciário. São Paulo, ano XVI, nº 78, pp. 22-16, maio/jun. 2017.

DANELUZZI, Maria Helena Marques Braceiro e MATHIAS, Maria Ligia Coelho. Repercussão do Estatuto da Pessoa com Deficiência (Lei 13.146/2015), nas legislações civil e processual civil. Revista de Direito Privado. São Paulo, vol. 66, pp. 57-82, abril/jun.2016.

DIAS, Maria Berenice. Manual de Direito das Famílias. São Paulo: Revista dos Tribunais, 2015.

DIDIER JR. Fredie. Da interdição. In WAMBIER, Teresa Arruda Alvim; DIDIER JR. Fredie; TALAMINI, Eduardo; DANTAS, Bruno. (coords.). Breves Comentários ao Novo Código de Processo Civil. $3^{\underline{a}}$ ed. São Paulo: Revista dos Tribunais, 2016.

DIDIER JR. Fredie. Estatuto da pessoa com deficiência, código de processo civil de 2015 e código civil: uma primeira reflexão. Disponível em http://www.frediedidier.com.br/. Acesso 27de novembro de 2017.

FARIAS, Cristiano Chaves; CUNHA, Rogério Sanches e PINTO, Ronaldo Batista. Estatuto da pessoa com deficiência comentado artigo por artigo. 2a ed. Salvador: Juspodivm, 2016.

FARIAS, Cristiano Chaves de e ROSENVALD, Nelson. Curso de direito civil: parte geral e LINDB. $14^{\mathrm{a}}$ ed. Salvador: Juspodivm, 2016.

GODINHO, Robson Renault. Comentários ao Código de Processo Civil - Dos procedimentos de jurisdição voluntária. GOUVEA, José Roberto e outros (coord.). São Paulo: Saraiva Educação, 2018, p. 376.

GRAU, Eros Roberto. Nota sobre a distinção entre obrigação, dever e ônus. Revista da Faculdade de Direito da Universidade de São Paulo. São Paulo, vol. 77. Disponível em www.revistas.usp.br. Acesso 03 de janeiro de 2018. 
LIMA, Alcides Mendonça. Comentários ao Código de Processo Civil. São Paulo: RT, 1982, vol. VII.

MACHADO, Diego Carvalho. Capacidade de agir e direitos da personalidade no ordenamento jurídico brasileiro: o caso do direito à privacidade. Revista Brasileira de Direito Civil. Belo Horizonte, vol. 8, n², pp. 47-80, abr./jun.2016.

MARQUES, Cláudia Lima. MIRAGEM, Bruno. O novo direito privado e a proteção dos vulneráveis. São Paulo: Editora Revista dos tribunais, 2012, p. 111.

MARTINS, Silvia Portes Rocha. O Estatuto da pessoa com deficiência e as alterações jurídicas relevantes no âmbito da capacidade civil. Revista dos Tribunais. São Paulo, vol. 105, nº 974, pp. 225-243, dez. 2016.

MELLO, Marcos Bernardes. Teoria do fato jurídico: Plano da existência. 13a ed. São Paulo: Saraiva, 2007.

MENEZES CORDEIRO, António. Tratado de direito civil português. Parte geral. 2a ed. Coimbra: Almedina, 2000, t. I.

MENEZES, Joyceane Bezerra de e CORREIA NETO. Jader de Figueiredo. Interdição e curatela no NOVO CPC à luz da dignidade da pessoa humana e do direito civil constitucional. In Relações Privadas e Democracia. Conpedi, 2014. Disponível em www.publicadireito.com.br. Acesso 27 de outubro de 2017.

MENEZES, Joyceane Bezerra de. O direito protetivo no Brasil após a convenção sobre a proteção da pessoa com deficiência: impactos do novo CPC e do Estatuto da Pessoa com Deficiência. Revista Eletrônica de Direito Civil. № 1, ano 4, 2015. Disponível em http://civilistica.com. Acesso 15 de novembro de 2017.

MENEZES, Joyceanne Bezerra de. O risco de retrocesso: uma análise sobre a proposta de harmonização dos dispositivos do Código Civil, do CPC, do EPD e da CDPD a partir da alteração da Lei no 13.146 de 06 de julho de 2015. Revista Brasileira de Direito Civil. Belo Horizonte, vol. 12, pp.137-171, abril/jun.2017. Disponível em www.ibdcivil.org.br. Acesso 01 de agosto de 2018.

NERY, Rosa Maria Barreto Borriello de Andrade. O Estatuto da Pessoa com Deficiência (L. 13146, de 6.7.2015 - EPD) (Notícia do Novo Sistema Jurídico Brasileiro). Revista Jurídica Luso-Brasileira. Ano 2, ${ }^{\circ}$ 1, pp. 1541-1561, 2016. Disponível em www.cidp.pt. Acesso 12 de julho de 2018.

OLIVEIRA, Leonardo Alves de. O Estatuto da Pessoa com Deficiência (Lei n. 13.146/2015), seus direitos e o novo paradigma da capacidade civil. Revista Síntese direito previdenciário. São Paulo, Ano XVI, no 78, pp.50-61, maio/jun. 2017.

PONTES DE MIRANDA, Francisco Cavalcanti. Comentários ao Código de Processo Civil. 2ª ed. São Paulo: Forense, 1959, t. VIII.

REICHER, Stella Camlot. A capacidade legal das pessoas com deficiência. Disponível em www.apaesp.org. br. Acesso 05 de junho de 2018.

REQUIÃO, Maurício. As mudanças na capacidade e a inclusão da tomada de decisão apoiada a partir do Estatuto da pessoa com deficiência. Revista de Direito Contemporâneo. São Paulo, vol. 6, ano 3, pp. 3754, jan./mar.2016, p.46. Disponível em http://www.egov.ufsc.br. Acesso 15 de novembro de 2017.

REQUIÃO. Maurício. Estatuto da Pessoa com Deficiência, Incapacidade e Interdição. Salvador: Juspodivm, 2016.

RIBEIRO, Geraldo Rocha. A protecção do incapaz adulto no direito português. Coimbra: Coimbra Editora, 2010 .

RIBEIRO, Moacyr Petrocelli de Ávila. Estatuto da pessoa com deficiência: a revisão da teoria das incapacidades e os reflexos jurídicos na ótica do notário e do registrador. Colégio Notarial do Brasil Conselho Federal. Disponível em www.notariado.org.br. Acesso 17 de maio de 2018.

SANTOS, Ivana Assis Cruz dos. O Estatuto da Pessoa com Deficiência e as Alterações no Código Civil de 2002. Revista Sintese direito previdenciário. São Paulo, no 78, ano XVI , pp. 27-36, maio/jun. 2017.

SCHENK, Leonardo Faria. Notas sobre a interdição no Código de Processo civil de 2015. Revista Eletrônica de Direito Processual - REDP. Vol. 15, jan./jun.2015. Periódico Semestral da Pós-Graduação 
Stricto Sensu em Direito Processual da UERJ. Disponível em www.e-publicacoes.uerj.b. Acesso 29 de novembro de 2017.

STOLZE, Pablo e PAMPLONA FILHO, Rodolfo. Novo curso de direito civil. Parte Geral.14ª ed. E-book. São Paulo: Saraiva, 2012, vol.1.

VIEGAS, Cláudia Mara de Almeida Rabelo. As alterações da teoria das incapacidades, à luz do Estatuto da Pessoa com Deficiência. Revista Síntese direito previdenciário. São Paulo, ano XVI, nº 78, pp. 9-16, maio/jun. 2017. 